\title{
Analysis of Yield Attributing Characters of Different Genotypes of Wheat in Rupandehi, Nepal
}

\author{
Gobinda Pandey ${ }^{1 *}$, Laxmeshwar Yadav ${ }^{1}$, Anand Tiwari ${ }^{1}$, Hom Bahadur Khatri ${ }^{1}$, Samsher \\ Basnet $^{1}$, Kamal Bhattarai ${ }^{1}$, Binod Gyawali ${ }^{1}$, Nabin Rawal ${ }^{2}$, Narayan Khatri ${ }^{2}$ \\ *Corresponding author email: gobi8448@ gmail.com \\ ${ }^{1}$ Institute of Agriculture and Animal Science, Paklihawa, Rupandehi, Nepal \\ ${ }^{2}$ National Wheat Research Program, Bhairahawa, Rupandehi, Nepal
}

\begin{abstract}
Field experiment was conducted at National Wheat Research Program, Bhairahawa, Rupandehi with the objective to identify high yielding superior wheat genotypes for Rupandehi district of Nepal during 2014. Experiment was laid out in one factorial Randomized completely block design with ten wheat genotypes including both released and promising; Annapurna 1, Annapurna 3, Pasang Lahmu, Bijaya, BL 3623, Bhirkuti, NL 297, BL 4316, BL 3978 and BL 4347 with three replications. The results showed that the grain yield of $B L$ 3978 was found higher (4.03 $t \mathrm{ha}^{-1}$ ) than other genotypes followed by BL 4347 (3.93t ha $\left.\mathrm{h}^{-1}\right)$. BL 3978 have also higher number of effective tillers $m^{-2}$ and test weight. Among release varieties, NL 297 show higher yield (4t

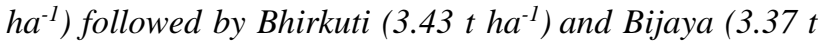
$\mathrm{ha}^{-1}$ ). From this experiment it can be concluded that BL 3978 was found promising among all genotypes however should be tested at on-farms before promoted for general cultivation in Rupandehi district of Nepal.
\end{abstract}

Keywords- Genotypes, Wheat, Yield.

\section{INTRODUCTION}

Agriculture contributes on an average 33 percent to Gross Domestic Product and employs 65.7 percent of the labor force in Nepal [1]. Wheat is the third most important crop after rice and maize, but in terms of human consumption it ranks second. Wheat is grown in different agroecological zones and environments with different production potentials. It is cultivated on 745,823 hectares of land and has the production of $1,736,849$ tones with average productivity of 2.32 ton $\mathrm{hac}^{-1}$ in Nepal [2]. Cereals crop share about $37 \%$ to agricultural GDP, among this wheat share about $7.14 \%$ [3]. It occupies $24 \%$ of total cereal area and contributes $20 \%$ of the total cereal production in Nepal [2]. Most of the wheat area (57.8\%) and production $(65.2 \%)$ occurred in terai region which occupy only $23 \%$ of the total land area of Nepal [2]. Improved varieties cover about $95.8 \%$ of the total wheat area whereas, $66.21 \%$ of total wheat crop area is grown under irrigated environment [2].

National Wheat Development Programme was established in 1972 to organize the research and development works on wheat as a commodity crop. Since then, there have been great achievements brought out by the consolidated efforts of wheat researchers, extension workers and farmers. So far there are 35 improved wheat cultivars and $90 \%$ of the wheat area is covered by modern wheat cultivars in Nepal [4]. Nepal Agriculture Research Council [5] mentioned that performance in wheat production in Nepal has increased remarkably due to wide spread cultivation of high yielding varieties since 1972. In fact Department of Agriculture had launched a "Grow More Wheat Campaign" in 1965/66 with the introduction of Mexican wheat varieties introduced via India. The new varieties of seed were launched since then and now occupy $96 \%$ in 2006/2007 [6]. There are altogether 30 varieties developed for different environment in Nepal [7]. During the last 38 years period from 1970/71 to $2007 / 08$ the production of wheat in the Terai region increased from $81,600 \mathrm{Mt}$ to 1,040,535 Mt [8]. One of the reasons for increase in wheat yield is the use of improved seeds. About $97 \%$ of seeds used in Nepal during 2007/ 2008 [9] was improved. With availability of the high yielding varieties as well as improved irrigation facilities in terai, wheat yield has increased more than three times in the terai. The low productivity of wheat in Nepal is mainly due to three reasons; low yielding varieties, low use of production inputs like seeds, fertilizer etc, and lack of irrigation and poor soil fertility management practices [10].

Therefore this study was conducted at National Wheat Research Program Bhairahawa, Rupandehi, Nepal in 2014/15 during winter seasons in order to identify high yielding superior wheat genotypes for Rupandehi district of Nepal. 


\section{MATERIALS AND METHODS}

\section{Location, Climate and Weather Condition}

A field experiment was conducted at NWRP (National Wheat Research Program) farm, Bhairahawa, Rupandehi which is located in the south part of Rupandehi and near the India border (Figure 1). This area is located at latitude $27^{\circ} 30^{\prime} 0^{\prime \prime} \mathrm{N}$ and longitude $83^{\circ} 27^{\prime} 0^{\prime \prime} \mathrm{E}$. Weather and climate of this area is around $40^{\circ} \mathrm{C}$ in summer season and $10^{\circ} \mathrm{C}$ in winter season. Average Monthly Rainfall: 545.6 $\mathrm{mm}$.

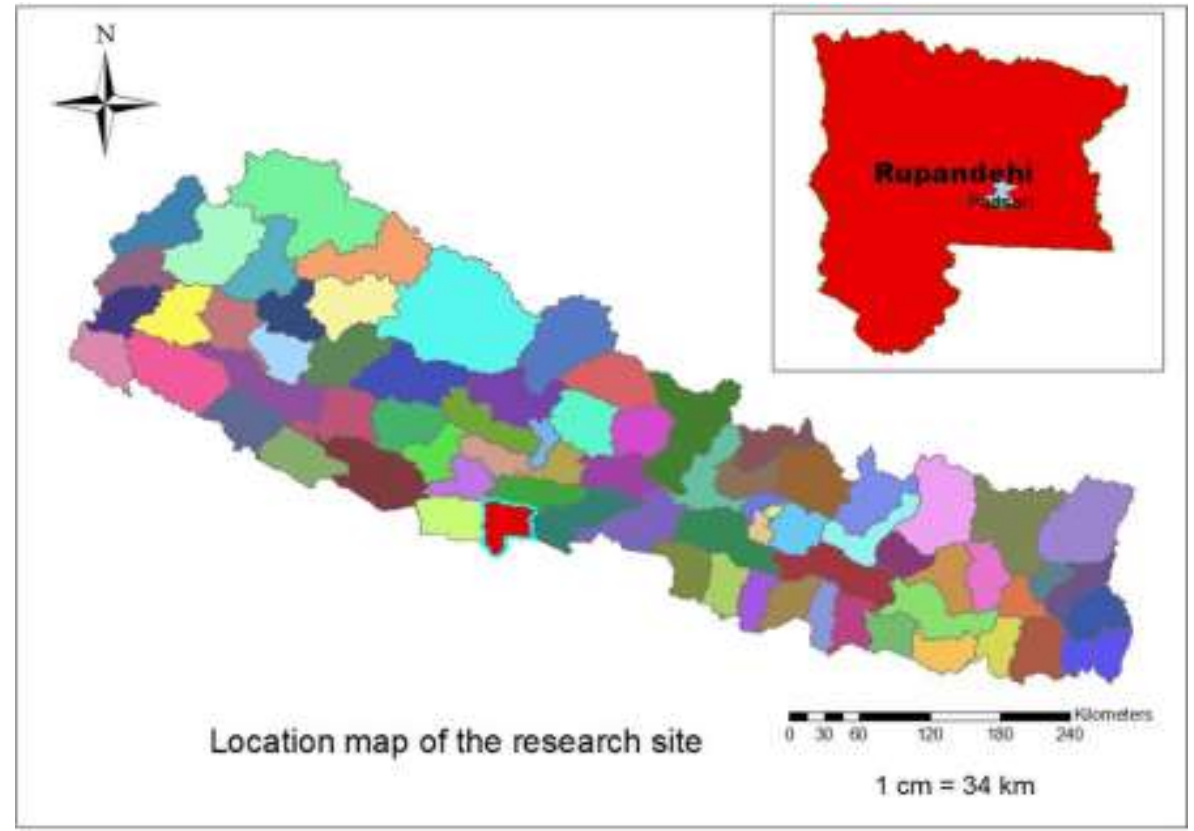

Fig.1: Map of Rupandehi district sowing research site (NWRP, Bhairahawa)

\section{Design of the experimental plot and sowing}

The experimental plots were laid out in one factor RCB design consisted of 10 wheat genotypes (Annapurna 1, Annapurna 3, Pasang Lahmu, Bijaya, BL 3623, Bhirkuti, NL 297, BL 4316, BL 3978 and BL 4347) with three replications. Each replication was separated by $2 \mathrm{~m}$ tally, while the plot was separated by $1 \mathrm{~m}$. The size of the individual plot was $3 \mathrm{~m} \times 2 \mathrm{~m}$ i.e. $6 \mathrm{~m}^{2}$. Spacing between row to row was $25 \mathrm{~cm}$ and plant to plant is continuous, there was 12 rows of $2 \mathrm{~m}$ long. All wheat genotypes were sown on same date of 15 December of 2013 with seed rate of $120 \mathrm{~kg} \mathrm{ha}^{-1}$. Chemical fertilizer was applied @ 100:50:25 kg N: $\mathrm{P}_{2} \mathrm{O}_{5}: \mathrm{K}_{2} 0 \mathrm{~kg} \mathrm{ha}^{-1}$. Half dose of nitrogen, full dose of phosphorus $\left(50 \mathrm{~kg} \mathrm{ha}^{-1}\right)$ and potash $\left(25 \mathrm{~kg} \mathrm{ha}^{-}\right.$ $\left.{ }^{1}\right)$ were applied as basal dose. Remaining half dose of nitrogen fertilizer was applied as top dress in two-split doses i.e. $1 / 4^{\text {th }}$ at CRI stage after first irrigation and $1 / 4^{\text {th }}$ at panicle initiation stage. Data collection based on plant height, spike length, effective tillers $\mathrm{m}-2$, number of grains per spike, grain yield $t$ ha-1, biomass yield $t$ ha-1, harvest index and test weight. Statistical analysis was done using Microsoft Office Excel, and MSTAT-C Package program.

\section{RESULTS AND DISCUSSION}

\section{Biometrical observation}

Plant height
Result revealed that plant height was highly significantly influenced by different genotypes. Plant height was observed maximum on Pasang variety $(111.1 \mathrm{~cm})$. Whereas minimum plant height was recorded on Bhirkuti $(66.87 \mathrm{~cm})$. Which was at par with BL $3623(73.4 \mathrm{~cm})$ (Table 1). The minimum plant height was due to varietal characters, lack of proper irrigation at CRI stage and soil condition. These results were in line with [11] who reported that the plant height was significantly different between genotypes.

\section{Spike length}

Spike length was highly significantly influenced by the different genotypes of wheat (Table 1). BL 3978 have more in length $(11.47 \mathrm{~cm})$ and it was at par with NL 297 $(11.27 \mathrm{~cm})$ and Pasang $(11.2 \mathrm{~cm})$. And the shortest spike length was observed in Bijaya $(8.06 \mathrm{~cm})$. Which was at par with Annapurna $1(8.46 \mathrm{~cm})$ (Table 1). These results were in line with [11] who reported that the spike length was significantly different between genotypes.

Effect of genotypes on yield attributing traits of wheat Effective tillers per square meter

Among yield attributing components, productive tillers are very important because the final yield is mainly a function of the number tillers bearing spike per unit area. The effective tillers $\mathrm{m}^{-2}$ was highly influences by different genotypes significantly (Table 1). An average effective tiller $\mathrm{m}^{-2}$ was recorded in the experiment was 217 . 
Among cultivars, BL 3978 showed higher effective tillers $\mathrm{m}^{-2}$ (285) (Table 1), which was followed by BL 4347 (270). Whereas lower effective tillers was given by Pasang (179), which was at par with Annapurna 1 (182) and BL 3623 (189). Significant difference in effective tillers among the cultivars might be due to their genotypic characteristic. These results were in line with [11] who reported that the productive tiller was significantly different between genotypes. Our finding was also confirmed by [12].

\section{Number of total grains per spike}

Genotypes highly influenced the number of grains per spike significantly (Table 1). The average number of grains per panicle was found 40. Higher number of grains spike- ${ }^{1}$ was found in Annapurna 1 (52) followed by
Bhirkuti (46). Lowest number of grains spike ${ }^{-1}$ was found in BL 4316 (30) followed by BL 4347 (32) (Table 1). These results were in line with [11] who reported that the number of total grains per spike was significantly different between genotypes. Quite identical results were obtained by [13, 14, 15 and 16].

\section{Thousand grains weight (Test weight)}

Effect of genotype on thousand grains weight was highly significant (Table 1). Comparatively higher test weight was found in BL 3623 (40.7 g) followed by Bijaya (40.1 g). Annapurna 3 has minimum test weight $(29.1 \mathrm{~g})$ followed by Pasang (29.2 g) (Table 1). Higher test weight was found due to varietal characters as well as sufficient moisture during the growing period. [17] Also found that test weight was significantly influenced by the genotypes.

Table.1: Effect of genotypes on grain yield, biomass yield and harvest index of wheat at National Wheat Research Program, Bhairahawa, Rupandehi, 2014

\begin{tabular}{|c|c|c|c|c|c|}
\hline Genotypes & Plant height $(\mathbf{c m})$ & Spike length $(\mathbf{c m})$ & $\begin{array}{l}\text { Effective tillers } \\
\mathbf{m}^{-2}\end{array}$ & $\begin{array}{l}\text { Total grains } \\
\text { spike }^{-1}\end{array}$ & $\begin{array}{l}\text { Test weight } \\
\text { (g) }\end{array}$ \\
\hline Annapurna 1 & $74.4^{\text {cd }}$ & $8.467^{\mathrm{de}}$ & $182^{\mathrm{d}}$ & $52^{\mathrm{a}}$ & $32^{\mathrm{de}}$ \\
\hline Annapurna 3 & $81^{\mathrm{bc}}$ & $8.667^{\mathrm{d}}$ & $200^{\mathrm{bcd}}$ & $41^{\text {bcd }}$ & $29.1^{\mathrm{e}}$ \\
\hline Pasang & $111.1^{\mathrm{a}}$ & $11.2^{\mathrm{a}}$ & $179^{\mathrm{d}}$ & $35^{\text {cdef }}$ & $29.2^{\mathrm{e}}$ \\
\hline Bijaya & $82.87^{\mathrm{b}}$ & $8.067^{\mathrm{e}}$ & $222^{\mathrm{b}}$ & $42^{\mathrm{bc}}$ & $40.1^{\mathrm{a}}$ \\
\hline BL 3623 & $73.4 d^{e}$ & $8.8^{\mathrm{d}}$ & $189^{\mathrm{cd}}$ & $44^{\mathrm{b}}$ & $40.7^{\mathrm{a}}$ \\
\hline Bhirkuti & $66.87^{\mathrm{e}}$ & $8.933^{\mathrm{cd}}$ & $222^{\mathrm{b}}$ & $46^{\mathrm{ab}}$ & $35.1^{\mathrm{cd}}$ \\
\hline NL 297 & $74.07^{\mathrm{cd}}$ & $11.27^{\mathrm{a}}$ & $213^{\mathrm{bc}}$ & $34^{\mathrm{def}}$ & $36.03^{\mathrm{bc}}$ \\
\hline BL 4316 & $75.47^{\mathrm{cd}}$ & $10.0^{\mathrm{b}}$ & $209^{\mathrm{bc}}$ & $30^{\mathrm{f}}$ & $39.3^{\mathrm{ab}}$ \\
\hline BL 3978 & $85.73^{\mathrm{b}}$ & $11.47^{\mathrm{a}}$ & $285^{\mathrm{a}}$ & $39^{\text {bcde }}$ & $37.9^{\mathrm{ab}}$ \\
\hline BL 4347 & $78.73^{\mathrm{bcd}}$ & $9.333^{\mathrm{c}}$ & $270^{\mathrm{a}}$ & $32^{\mathrm{ef}}$ & $31^{\mathrm{e}}$ \\
\hline $\mathrm{F}$ test & $* *$ & $* *$ & $* *$ & $* *$ & *** \\
\hline SEM & 2.21 & 0.1643 & 8.347 & 2.293 & 1.05 \\
\hline $\operatorname{LSD}(0.05)$ & 6.565 & 0.4882 & 24 & 6 & 3.129 \\
\hline Grand mean & 80.36 & 9.6 & 217 & 40 & 35.07 \\
\hline $\mathrm{CV}(\%)$ & 4.76 & 2.95 & 6.65 & 10.04 & 5.2 \\
\hline
\end{tabular}

Means followed by the common letter (s) within each column are not significantly different among each other based on DMRT at $5 \%$ level of significance. F: test: ** denotes highly significance at $1 \%$ level

\section{Effect of genotypes on yield and harvest index Grain yield}

Grain yield is determined by the yield attributing traits of the crop. The yield of the particular crop in a location is a combined effect of genetic makeup of the cultivar, growing environment and the crop management practices. Grain yield is a function of yield attributing traits, primarily productive tillers, numbers of grains per spike and thousand grains weight etc.

Grain yield was highly significantly influence by the genotypes (Table 2). Higher grains yield $\mathrm{t} \mathrm{ha}^{-1}$ was obtain in BL 3978 (4.03 $\left.\mathrm{t} \mathrm{ha}^{-1}\right)$ followed by NL 297 (4.0 $\left.\mathrm{t} \mathrm{ha}^{-1}\right)$ and BL 4347 (3.93 $\mathrm{t} \mathrm{ha}^{-1}$ ) (Table 2). Lowest yield was observed in Annapurna 3 (2.33 $\left.\mathrm{t} \mathrm{ha}^{-1}\right)$ followed by the Annapurna 1 (2.77 t ha-1) and Pasang (2.80 t ha-1) (Table 2). Low yield was found in these varieties due to their genotypic characters because they were recommended variety for hilly region; they show low performance in terai region.

[18] also found that grain yield was significantly influence by the genotypes. He also found that Gautam produced significantly higher yield than Bhrikuti and BL1473 under both the tillage practices. However, 
Bhrikuti also produced significantly higher grain yield than BL1473 under conventional tillage.

\section{Biomass yield}

Biomass yield was found to be highly significantly influenced among all genotypes (Table 2). Maximum biomass yield was observed in Bhirkuti and BL 3978 (8.3 $\mathrm{t} \mathrm{ha}^{-1}$ ) followed by BL $4347\left(8.13 \mathrm{t} \mathrm{ha}^{-1}\right)$ (Table 2). Low biomass yield was found in BL $3623\left(4.83 \mathrm{t} \mathrm{ha}^{-1}\right)$. Low biomass was due to the low straw yield in BL 3623 (1.23 $\left.\mathrm{t} \mathrm{ha}^{-1}\right)$ but have higher grain yield $\left(3.6 \mathrm{t} \mathrm{ha}^{-1}\right)$ (Table 2). [18] supported our above results for biomass yield, which was significantly influenced by different genotypes.

\section{Harvest index}

Harvest index was found to be highly significantly influenced among all genotypes (Table 2). Maximum Harvest index was observed in BL 3623 (0.74) (Table 2). Whereas low Harvest index was observed in Annapurna 3 (0.33) followed by Annapurna 1 (0.37). Low harvest index was due to these variety was recommended to hilly region; they show low performance in terai region. [12] also found that harvest index was significantly differs in all genotypes.

Table.2: Effect of genotypes on grain yield, biomass yield and harvest index of wheat at National Wheat Research Program, Bhairahawa, Rupandehi, 2014

\begin{tabular}{|c|c|c|c|}
\hline Genotypes & Grain yield $\left(t h^{-1}\right)$ & Biomass yield $\left(\mathrm{t} \mathrm{ha}^{-1}\right)$ & Harvest index (HI) \\
\hline Annapurna 1 & $2.77^{\mathrm{c}}$ & $7.3^{\mathrm{de}}$ & $0.37^{\mathrm{i}}$ \\
\hline Annapurna 3 & $2.33^{\mathrm{d}}$ & $7.06^{\mathrm{def}}$ & $0.33^{\mathrm{j}}$ \\
\hline Pasang & $2.80^{\mathrm{c}}$ & $6.7^{\mathrm{f}}$ & $0.41^{\mathrm{g}}$ \\
\hline Bijaya & $3.43^{\mathrm{b}}$ & $7.8^{\mathrm{bc}}$ & $0.43^{\mathrm{f}}$ \\
\hline BL 3623 & $3.60^{\mathrm{b}}$ & $4.83^{\mathrm{g}}$ & $0.74^{\mathrm{a}}$ \\
\hline Bhirkuti & $3.37^{\mathrm{b}}$ & $8.3^{\mathrm{a}}$ & $0.40^{\mathrm{h}}$ \\
\hline NL 297 & $4.0^{\mathrm{a}}$ & $7.5^{\mathrm{cd}}$ & $0.53^{\mathrm{c}}$ \\
\hline BL 4316 & $3.50^{\mathrm{b}}$ & $6.83^{\mathrm{ef}}$ & $0.54^{\mathrm{b}}$ \\
\hline BL 3978 & $4.03^{\mathrm{a}}$ & $8.3^{\mathrm{a}}$ & $0.47^{\mathrm{e}}$ \\
\hline BL 4347 & $3.93^{\mathrm{a}}$ & $8.13^{\mathrm{ab}}$ & $0.48^{\mathrm{d}}$ \\
\hline F test & $* *$ & $* *$ & $* *$ \\
\hline SEM & 0.089 & 0.15 & 0.0057 \\
\hline $\operatorname{LSD}(0.05)$ & 0.266 & 0.447 & 0.0017 \\
\hline Grand mean & 3.38 & 7.27 & 0.46 \\
\hline $\mathrm{CV}(\%)$ & 4.59 & 4.58 & 4.51 \\
\hline
\end{tabular}

Means followed by the common letter (s) within each column are not significantly different among each other based on DMRT at $5 \%$ level of significance. F: test: ** denotes highly significance at $1 \%$ level

\section{Correlation regression studies}

To assess the relationship between growth parameters, yield attributing traits and grain yield simple correlation coefficients were worked out. The number of effective tillers $\mathrm{m}^{-2}$ contribute approximately $44.8 \%\left(\mathrm{R}^{2}=0.488\right)$ on the grain yield. Whereas the remaining $55 \%$ increase in grain yield may be due to other variables (Figure 2). Similarly, approximately $26 \%\left(\mathrm{R}^{2}=0.26\right)$ contribution by test weight on the grain yield and the left $74 \%$ increase in the grain yield by the other variables except test weight (Figure 3). Whereas grain yield contributed about $36 \%\left(\mathrm{R}^{2}=36\right)$ towards increase in the harvest index (Figure 4). And the remaining 64\% increase in the harvest index by the other variables rather than harvest index. 


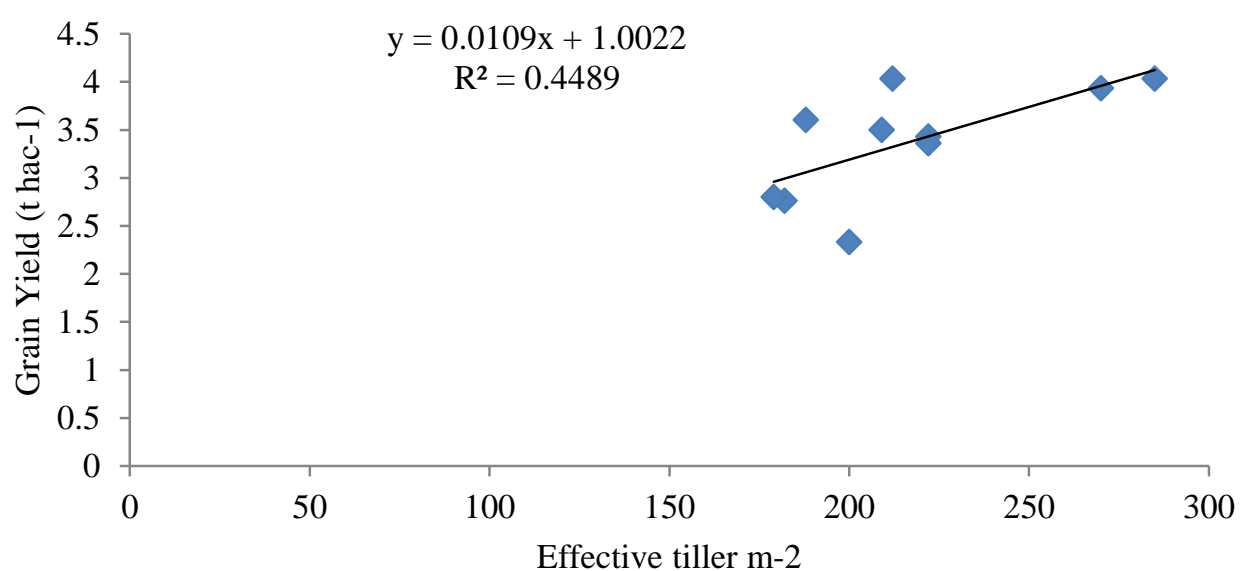

Fig.2: Relationship between grain yield and number of effective tillers per square meter of wheat at NWRP (Bhairahawa),

Rupandehi, 2014

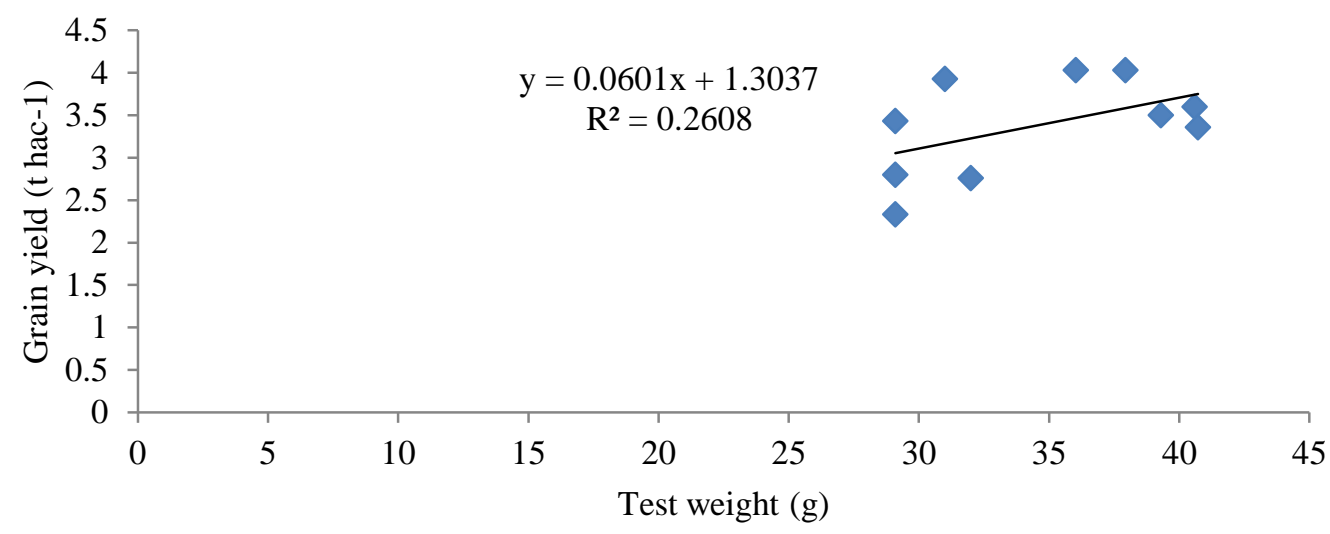

Fig.3: Relationship between grain yield and test weight ( $g$ ) of wheat at NWRP Bhairahawa, Rupandehi, 2014

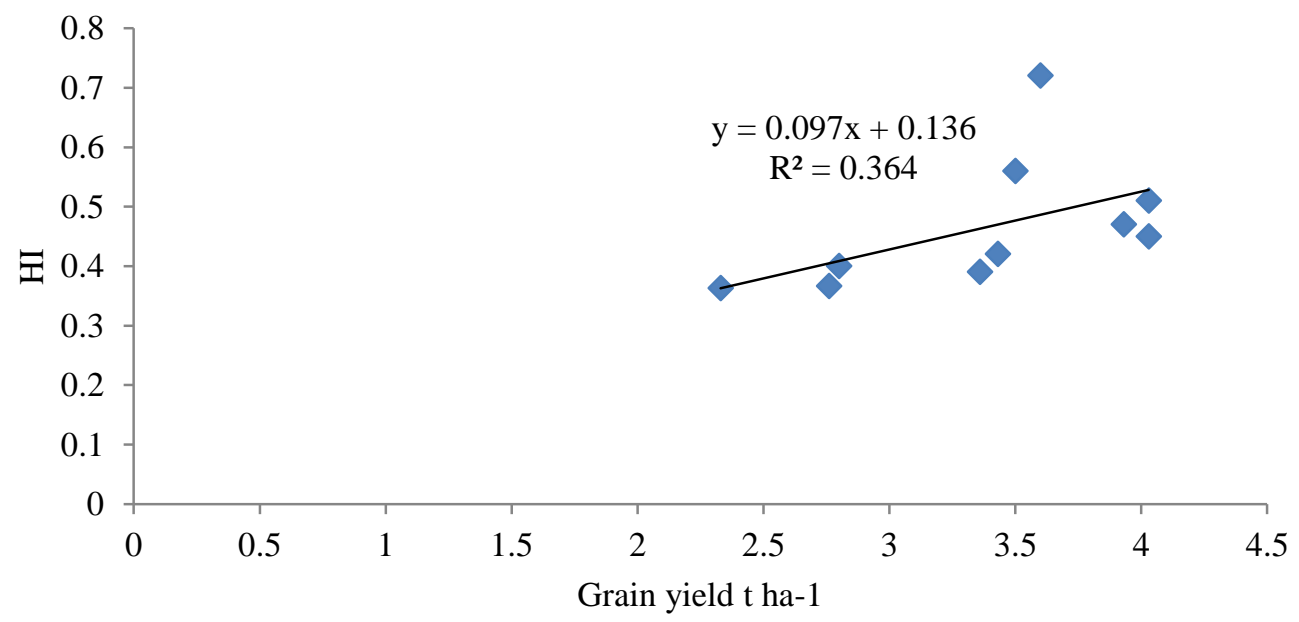

Fig.4: Relationship between grain yield and harvest index of wheat at NWRP Bhairahawa, Rupandehi, 2014

\section{CONCLUSION}

The grain yield of BL 3978 was found higher than other genotypes followed by BL 4347. BL 3978 have also higher number of effective tillers $\mathrm{m}^{-2}$ also have higher test weight. Higher biomass yield also found in the BL 3978.
Among release varieties NL 297 show higher yield followed by Bhirkuti and Bijaya. Bhirkuti show higher number of effective tillers $\mathrm{m}^{-2}$. Grain per spike also found higher in Bhirkuti and Bijaya. From our experiment we concluded that BL 3978 is higher yielder among all 
genotypes and NL 297 and Bhirkuti is found to high yielding varieties. However, at least three years of multilocation experiment will be needed to validate this research further.

\section{ACKNOWLEDGEMENT}

We would like to express our gratitude to National Wheat Research Program (NWRP), Bhairahawa for providing necessary research field, seed of different genotypes and technical support to conduct this experiment. Our sincere thanks go to Institute of Agriculture and Animal Sciences (IAAS), TU for all help and support.

\section{REFERENCES}

[1] MOAD, 2014. Statistical Information on Nepalese Agriculture, Ministry of Agricultural Development, 2014.

[2] MOAD, 2015/16. Statistical Information on Nepalese Agriculture, Ministry of Agricultural Development, 2015/16.

[3] MOAD, 2015. Selected Indicators of Nepalese Agriculture and Population. Government of Nepal, Ministry of Agricultural Development, AgriBusiness Promotion and Statistics Division, Singh durbar Kathmandu, Nepal.

[4] Bhatta, M.R., GO, Ferrera., B, Gurung., TP, Pokharel., NR, Gautum., P, Gurung and RB Neupane. 2000. Present status of participatory plant breeding research on wheat at the National Wheat Research Programme, Nepal. In: An exchange and experiences from South and South East Asia. Proceedings of the Intl. Symp. on PPB and PPGR enhancement, 1-5 May 2000, Pokhara, Nepal.PRGA, IDRC, DFID, DDS, LIBIRD, IPGRI and ICARDA.Pp. 391-398.

[5] NARC, 1997. 25 Years of wheat Research in Nepal (1972-1997), Nepal Agricultural Research Council, Kathmandu.

[6] MoAC, 2006. Statistical Information on Nepalese Agriculture, 2005/2006, Ministry of Agriculture and Coperatives, Kathmandu.

[7] NARC, 2007. Released and registered crop varieties in Nepal, Nepal Agricultural Research Council, Kathmandu.

[8] Nayava, J.L., 2008. Variations of rice yield with rainfall in Nepal during 1971-2000, Journal of Hydrology and Meteorology, Volume 1. pp. 93-102.

[9] MoAC, 2008. Statistical Information on Nepalese Agriculture, 2007/2008, Ministry of Agriculture and Coperatives, Kathmandu.

[10] Khadka, R.B. 2011. System of crop intensif ication: practice and experience, Forum for
Awareness and youth activity Nepal, Dhagadhi , Kailali.

[11] Ali, Y., B, Manzoor Atta, J, Akhter, P, Monneveux and Z, Lateef. 2008. Genetic Variability, Association and Diversity Studies in wheat (triticum aestivum 1.) Germplasm, Pak. J. Bot., 40(5): $2087-$ 2097.

[12] Anwar, J., M.A. Ali, M. Hussain, W. Sabir, M.A. Khan, M. Zulkiffal and M. Abdullah. 2009. Assessment of yield criteria in bread wheat through correlation and path analysis. The J. Animal \& Plant Sci. 19:185-188.

[13] Shahid, M., F. Muhammad and M. Tahir. 2002. Path coefficient analysis in wheat. Sar. J. Agric., 18: 383388.

[14]Ashfaq, M., A.S. Khan and Z. Ali. 2003. Association of morphological traits with grain yield in wheat (Triticum aestivum L.). Int. J. Agric. Bio., 5: 262-264.

[15] Nabi, T.G., M.A. Chowdhry, K. Aziz and W.M. Bhutta. 1998. Interrelationship among some polygenic traits in hexaploid spring wheat (Triticum aestivum L.). Pakistan J. Biol. Sci., 1:299-302.

[16] Aycicek, M. and T. Yildirim, 2006. Path coefficient analysis of yield and yield components in bread wheat (Triticum aestivum L.) genotypes. Pak. J. Bot., 38(2): 417-424.

[17] Tsegaye, D., T. Dessalegn, Y. Dessalegn and G. Share. 2012. Genetic variability, correlation and path analysis in durum wheat germplasm (Triticum durum Desf). Agric. Res. Rev. 1:107-112.

[18] Tripathi, J. 2010. Evaluation and promotion of resource conservation technologies in low land ricewheat Ecosystem, Agronomy Journal of Nepal, (Agron JN) Vol. 1. 